\title{
絶対制震理論によるアクティブ免震手法の実建物への適用*
}

\author{
吉田 治 $^{* 1}$, 蔭山 満 ${ }^{* 2}$, 佐野 剛志 ${ }^{* 2}$, 勝俣 英雄 ${ }^{* 2}$ \\ 遠藤 文明 ${ }^{* 3}$, 渡辺 哲巳 ${ }^{* 3}$, 山中 昌之 ${ }^{* 3}$
}

\section{Application of Active Base Isolation System Using Absolute Vibration Control Technology}

\author{
Osamu YOSHIDA *1 ${ }^{*}$, Mitsuru KAGEYAMA, Takeshi SANO, Hideo KATSUMATA \\ Fumiaki ENDO, Tetsumi WATANABE and Masayuki YAMANAKA \\ ${ }^{* 1}$ Obayashi Corporation, Technical Research Institute \\ Shimokiyoto 4-640, Kiyose-shi, Tokyo, 204-8558 Japan
}

An active base isolation system, which uses absolute vibration control technology, has been applied to the real full scale building, Obayashi Corporation Technical Research Institute Main Building ‘Techno-Station'. This building is the first active base isolation building all over the world. The absolute vibration control is an active vibration control method for base isolated structures to stay in the absolute space and to have vibration free environment, by applying control forces through actuators during earthquakes. Four $1100 \mathrm{kN}$ hydraulic actuators, two in each horizontal direction, are installed in the Techno Station to reduce the seismic response to 1/10 of the conventional passive base isolation system. When applying active control to a real full scale building, it is necessary to install fail safe mechanism in case that actuators are over-loaded by input ground motion of more than expected level or unstable control condition. As fail safe mechanism for this absolute vibration control, the trigger system using friction dampers has been developed and is installed between actuators and reaction foundations.

Key Words : Base Isolation, Active Control, Absolute Vibration Control, Actuator, Fail Safe Mechanism

\section{1. 緒言}

日本で初めて建設された免震事務所建物として, 1986 年に竣工した大林組技術研究所ハイテク R \& Dセンター がある(1).この建物の竣工後間もなく, 著者らは免震建物の基部免震層にアクティブ制御力を加えることで, 免 震建物を絶対空間に静止させ，加速度の低減を図ることを目的と寸る絶対制震理論の研究を行ってきた(2) (5). こ れらの研究では, 解析と振動台実験により, 絶対制震理論の制御効果が実証されたものの, 実建物への適用まで には到らなかった，その理由としては，免震構造として建物を支持する積層ゴムの水平剛性が当時は十分に柔ら かくなく, 必要なアクティブ装置の容量が実用可能な範囲内に設計できなかったこと，想定以上の大地震時や装 置トラブル時に対応するフェールセーフ機構が確立されていなかったことなどがあげられる.

その後, 約 20 年が経過し, 今回世界で初めて絶対制震理論によって地震時に摇れない建物の実現を目指したア クティブ免震手法を実建物へ適用した．本論文では，まずアクティブ免震手法の概要として，絶対制震理論及び 制御システムの概要を述べ，制御効果を実証するために行なった 3 階建て免震建物の縮小模型による振動台実験 の結果について報告する. さらに，実建物への適用に不可欠なフェールセーフ機構であるトリガー機構について 説明する. 次に，本手法を適用した建物である大林組技術研究所本館「テクノステーション」の概要とアクティ ブ制御装置の構成について紹介し，実建物の地震時応答解析結果の報告を行なう.

\footnotetext{
* 原稿受付 2011 年 10 月 24 日

*1 正員，（株）大林組＼cjkstart技術研究所（广204-8558 東京都清瀬市下清戸 4-640）

*2 (株) 大林組 技術研究所

*3 (株) 大林組 構造設計部

E-mail: yoshida.osamu@obayashi.co.jp
} 


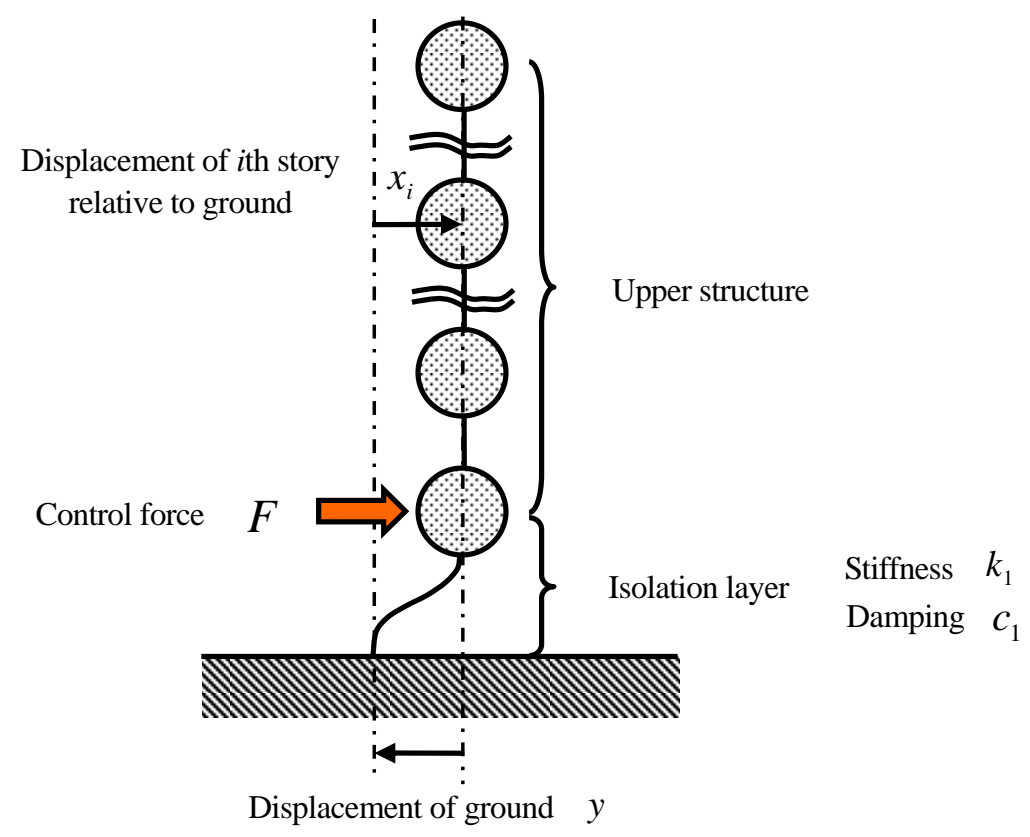

Fig. 1 MDOF base isolation system

\section{2. 絶対制震理論によるアクティブ免震手法の概要}

\section{$2 \cdot 1$ 絶対制震理論}

一般的に，図 1 に示すような最下層を免震層とする多質点系の免震建物の地震外力に対する運動方程式は，地 盤に対する相対座標系を用いて，次式のように表すことができる.

$$
M \ddot{X}+C \dot{X}+K X=-M\left\{\begin{array}{l}
1 \\
\vdots \\
1
\end{array}\right\} \ddot{y}
$$

ここで， $X=\left[\begin{array}{lll}x_{n} & \cdots & x_{1}\end{array}\right]^{T}$ : 建物各層の地動に対する相対変位ベクトル $\left(x_{i}: i\right.$ 層の地動に対する相対変 位), $M$ : 質量マトリックス, $C$ : 減衰マトリックス, $K$ : 剛性マトリックス, $\ddot{y}:$ 地動加速度である.

これを空中の仮想不動点を基準とした絶対座標系に変換すると，次式となる.

$$
M\left(\ddot{X}+\left\{\begin{array}{l}
1 \\
\vdots \\
1
\end{array}\right\} \ddot{y}\right)+C\left(\dot{X}+\left\{\begin{array}{c}
1 \\
\vdots \\
1
\end{array}\right\} \dot{y}\right)+K\left(X+\left\{\begin{array}{c}
1 \\
\vdots \\
1
\end{array}\right\} y\right)=\left\{\begin{array}{c}
0 \\
\vdots \\
0 \\
k_{1}
\end{array}\right\} y+\left\{\begin{array}{c}
0 \\
\vdots \\
0 \\
c_{1}
\end{array}\right\} \dot{y}
$$

ここで， $k_{1}$ : 免震層の剛性， $c_{1}$ : 免震層の減衰係数， $y$ : 地動変位， $\dot{y}:$ 地動速度である.

絶対制震の目的である建物の絶対応答をゼロにして建物を絶対空間上に静止させるためには，次式で示すよう に式(2)の外力を打ち消すように最下層にのみ制御力 $F$ を与えればよい.

$$
M\left(\ddot{X}+\left\{\begin{array}{c}
1 \\
\vdots \\
1
\end{array}\right\} \ddot{y}\right)+C\left(\dot{X}+\left\{\begin{array}{c}
1 \\
\vdots \\
1
\end{array}\right\} \dot{y}\right)+K\left(X+\left\{\begin{array}{c}
1 \\
\vdots \\
1
\end{array}\right\} y\right)=\left\{\begin{array}{c}
0 \\
\vdots \\
0 \\
k_{1}
\end{array}\right\} y+\left\{\begin{array}{c}
0 \\
\vdots \\
0 \\
c_{1}
\end{array}\right\} \dot{y}+\left\{\begin{array}{c}
0 \\
\vdots \\
0 \\
F
\end{array}\right\}
$$




$$
F=-k_{1} y-c_{1} \dot{y}
$$

この方法は応答の発生原因を先回りして入力を打ち消寸方法であるためフィードフォワード制御と呼ばれる. 本アクティブ免震システムでは，スピルオーバと呼ばれる建物の高次モードの発振による制御系の不安定現象 を防ぐとともに，アクチュエータからの高次振動数成分が建物に伝わるのを防ぐ目的で，アクチュエータと建物 間に「装置バネ」と呼ばれる柔らかいバネを設置している，つまり，アクチュエータからの制御力はこの装置バ ネを介して建物に作用される. 装置バネの剛性を $k_{s}$, アクチュエータのストローク変位を $z$ とすると, 建物に作 用される制御力は次式で表すことができる.

$$
F=k_{s}\left(z-x_{1}\right)
$$

式(5)を式(3)に代入すると次式となる.

$$
\begin{aligned}
& M\left(\ddot{X}+\left\{\begin{array}{l}
1 \\
\vdots \\
1
\end{array}\right\} \ddot{y}\right)+C\left(\dot{X}+\left\{\begin{array}{c}
1 \\
\vdots \\
1
\end{array}\right\} \dot{y}\right)+K_{Z}\left(X+\left\{\begin{array}{c}
1 \\
\vdots \\
1
\end{array}\right\} y\right)=\left\{\begin{array}{c}
0 \\
\vdots \\
0 \\
k_{1}+k_{s}
\end{array}\right\} y+\left\{\begin{array}{c}
0 \\
\vdots \\
0 \\
c_{1}
\end{array}\right\} \dot{y}+\left\{\begin{array}{c}
0 \\
\vdots \\
0 \\
k_{s}
\end{array}\right\} z \\
& \text { ただし, } K_{Z}=K+\left[\begin{array}{cccc}
0 & \cdots & 0 & 0 \\
\vdots & \ddots & \vdots & \vdots \\
0 & \cdots & 0 & 0 \\
0 & \cdots & 0 & k_{s}
\end{array}\right]
\end{aligned}
$$

従って, 式(6)の外力項を打ち消寸ためのアクチュエータ変位のフィードフォワード制御量は以下となる.

$$
z=-\left(\frac{k_{1}+k_{s}}{k_{s}}\right) y-\left(\frac{c_{1}}{k_{s}}\right) \dot{y}
$$

しかしながら，この制御法のみで地震時の入力を完全にゼロにすることは出来ない. なぜなら，地動の絶対変 位 $y$ と速度 $\dot{y}$ の観測誤差, および免震層の剛性 $k_{1}$ と減衰定数 $c_{1}$ およびアクチュエータ自身の特性によって, 入力 成分を完全に打ち消寸ことが出来ないためである，そこで，次式のように，上記フィードフォワード制御の誤差 によって励起された建物の絶対応答速度成分を観測して，それを即座に吸収するフィードバック制御を行う.

$$
z=-\frac{C_{s}}{k_{s}}\left(\dot{x}_{1}+\dot{y}\right)
$$

ここで， $c_{s}$ : フィードバックに用いる粘性係数である.この制御は，一般的にスカイフック・ダンパーと呼ば れる.

以上より，フィードフォワード制御（7）とフィードバック制御（8）を併用した絶対制震を行なうための指令 変位信号 $\mathrm{z}_{0}$ は次式となる。

$$
z_{0}=-\left(\frac{k_{1}+k_{s}}{k_{s}}\right) y-\left(\frac{c_{1}}{k_{s}}\right) \dot{y}-\left(\frac{c_{s}}{k_{s}}\right)\left(\dot{x}_{1}+\dot{y}\right)
$$




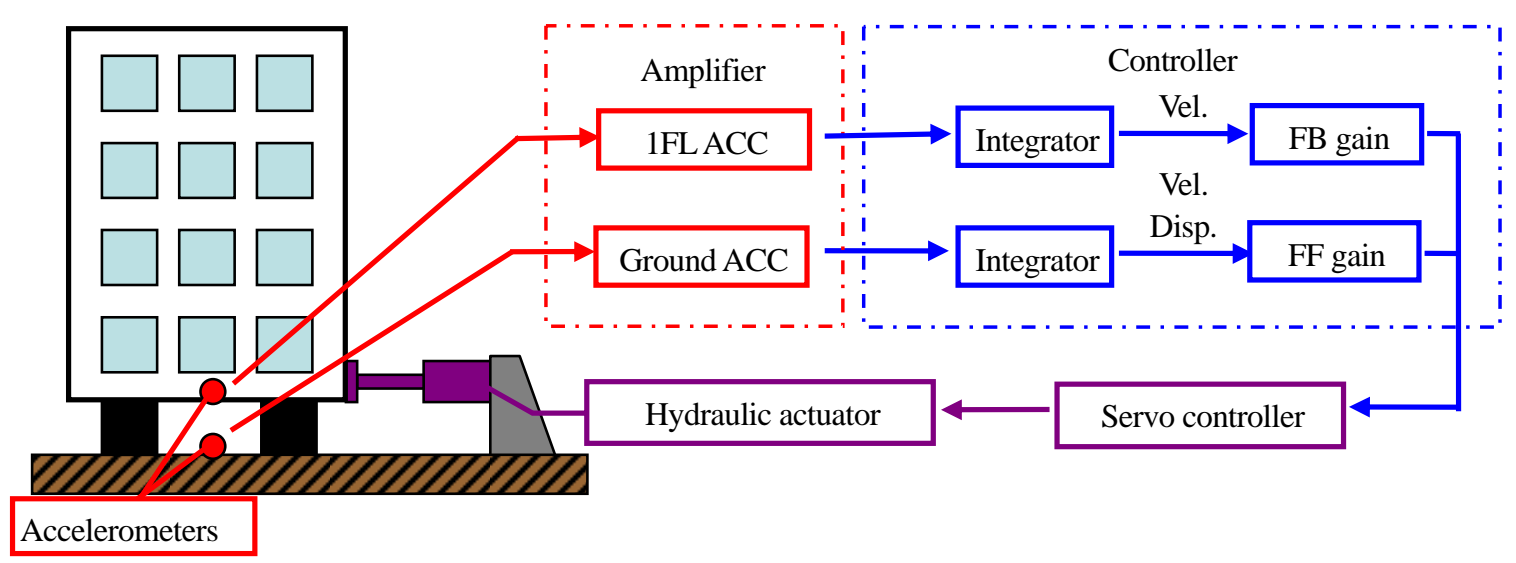

Fig. 2 Block diagram of control system

\section{$2 \cdot 2$ 制御システム}

図 2 に制御システムの概要図を示す．制御システムとしては，地盤と建物に設置された加速度センサー及びア ンプ，AD/DA と演算装置を備えたコントローラ，油圧サーボアクチュエータから成る.

前節で述べた絶対制震理論を実現するためには，地動の変位・速度と建物の絶対速度を計測する必要がある. しかしながら，地動変位を直接計測することは現実的に不可能なので，本システムでは，地盤に設置した加速度 センサーから得られる加速度信号をコントローラ内で積分することにより, 速度・変位に変換する手法を用いる. 建物の絶対速度についても同様に建物に設置した加速度センサーから得られる加速度信号を積分して速度に変換 する.

加速度センサーからの加速度信号を積分して速度，変位信号に変換する場合，通常の数值積分による方法だと 積分誤差の集積により，得られた速度や变位信号にドリフトが生じてしまい制御が発散してしまう。この問題を 解決するために，本システムでは 2 次遅れ系による疑似積分手法を採用することとした，その状態方程式を次式 に示す.

$$
\left\{\begin{array}{l}
\dot{y} \\
\ddot{y}
\end{array}\right\}=\left[\begin{array}{cc}
0 & 1 \\
-\omega_{f}{ }^{2} & -2 h_{f} \omega_{f}
\end{array}\right]\left\{\begin{array}{l}
y \\
\dot{y}
\end{array}\right\}+\left\{\begin{array}{l}
0 \\
1
\end{array}\right\} \ddot{y}_{0}
$$

ただし， $\ddot{y}_{0}$ : 加速度センサーからの加速度信号， $y, \dot{y}:$ 積分して得られる变位・速度， $\omega_{f}, h_{f}$ : 疑似積分フ イルタの遮断円振動数, 減衰比である.

ここで，疑似積分フィルタの遮断円振動数は，制御対象とする免震建物の固有振動数で位相迴りの影響が出な いように，それより十分に小さくする必要がある. 5 章で述べる実建物の免震周期は約 5.2 秒であることより， $\omega_{f}=2 \pi / 30$ とした. また, 減衰比は $h_{f}=1 / \sqrt{2}$ とした.

このようにして得られた地盤の変位・速度及び建物の絶対速度に式 (9) で示した絶対制震理論に基づく係数で あるフィードフォワードゲイン（FF ゲイン）及びフィードバックゲイン（FB ゲイン）を乗じて加算することに より，アクチュエータへの変位指令信号を作成してアクチュエータのサーボコントローラへ入力する.

\section{3. 縮小模型実験による制御効果の検証}

絶対制震理論による免震建物のアクティブ制御の制御効果を検証するために，三次元振動台を用いた制御実験 を行った.

\section{$3 \cdot 1$ 試験体概要}

試験体の概要図及び写真を図 3 , 図4に示寸.試験体は 3 層の鉄骨フレームモデルを用いた. 各層の質量は $2650 \mathrm{~kg}$ で， 1 層を含めた全質量は 10600kg である.この試験体は 4 個の積層ゴムで支持された免震建物モデルとなって 


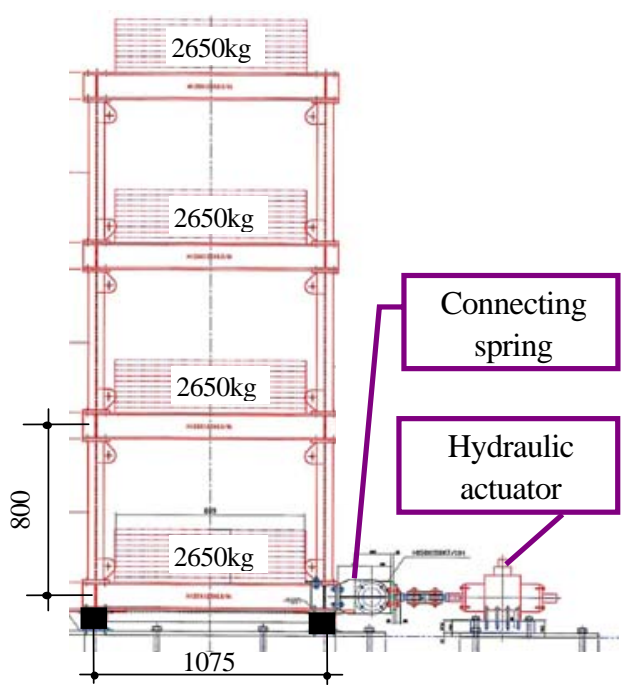

Fig. 3 Schematic of test structure
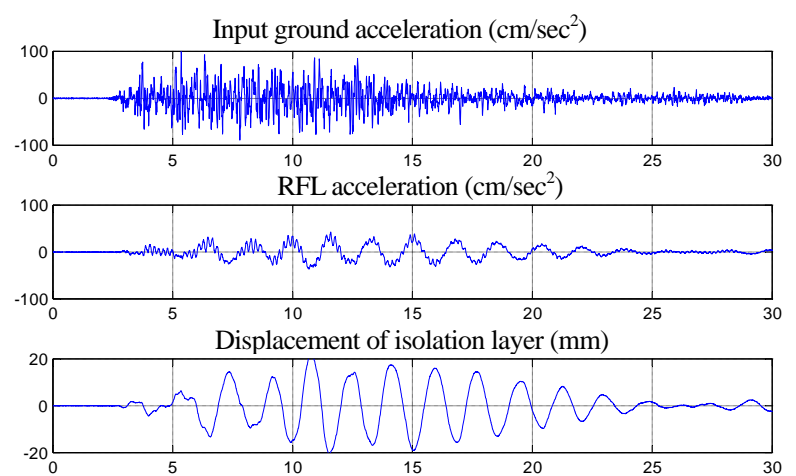

(a) Passive base isolation

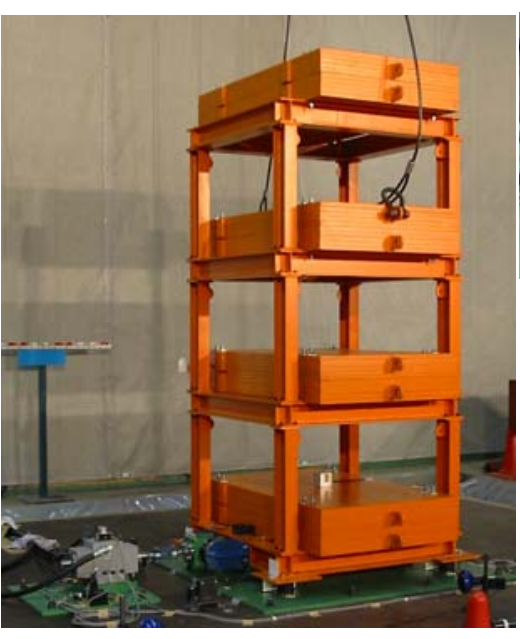

(a) Test structure

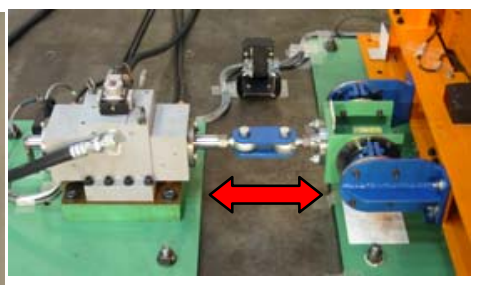

(b) Hydraulic actuator

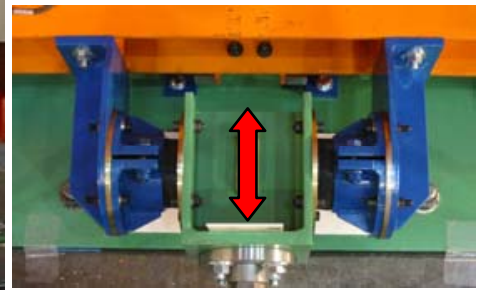

(c) Connecting spring

Fig. 4 Photos of test structure
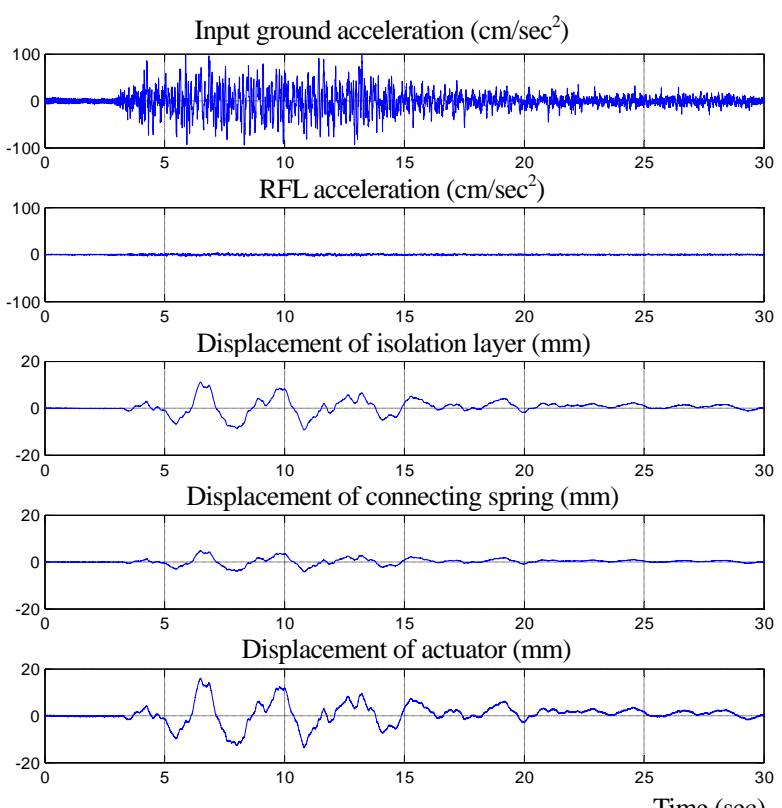

(b) Active base isolation

Fig. 5 Results of shaking table tests

おり, 免震周期は 1.6 秒である. アクティブ制御用のアクチュエータとしては, $24 \mathrm{kN}$ の油圧サーボアクチュエー タを設置した．装置バネとしては，免震建物を支持しているものと同じ積層ゴムを用い，その一部にたがをはめ て拘束することにより剛性を調整した。 免震層の剛性に対する装置バネの剛性比 $k_{s} / k_{1}$ は約 2.5 である.

本試験体にはダンパーは設置していないが, 積層ゴムの減衰によりパッシブ免震では $5.5 \%$ の減衰を有している.

\section{$3 \cdot 2$ 実験結果}

振動台に地震波入力を行ったときの実験結果を図 5 に示寸. 入力波は 5 章にて後述する告示波 (乱数位相) で, 実建物の免震周期 5.2 秒と試験体の免震周期 1.6 秒の比を考慮して, 時間軸を $1 / 3$ に短縮して実験を行った.

この結果より，アクチュエータを試験体から切り離して行なったパッシブ免震の結果では, 建物頂部の加速度 は地動入力加速度に対して $1 / 2$ 以下に低減されているものの, 免震周期 1.6 秒で大きく振動しており, 免震層変 


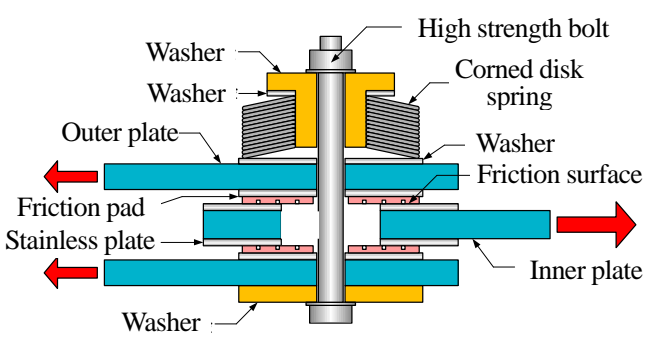

Fig. 6 Schematic of friction mechanism

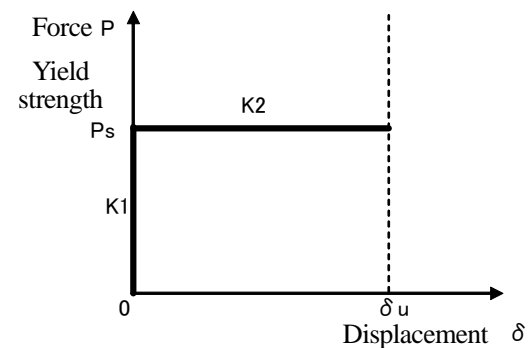

Fig. 7 Characteristic of friction damper

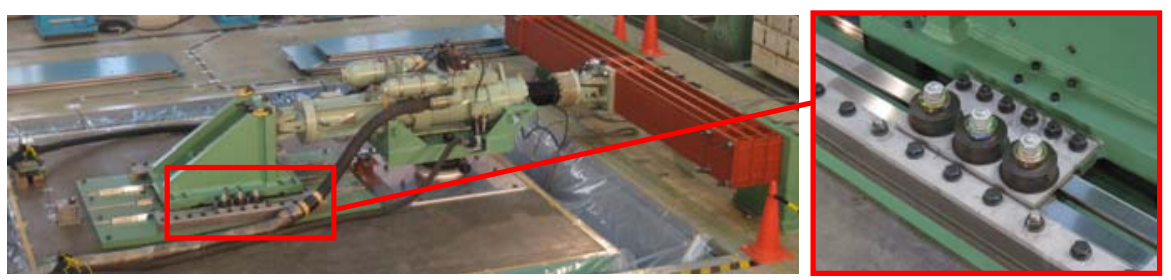

Fig. 8 Photos of full scale trigger system test

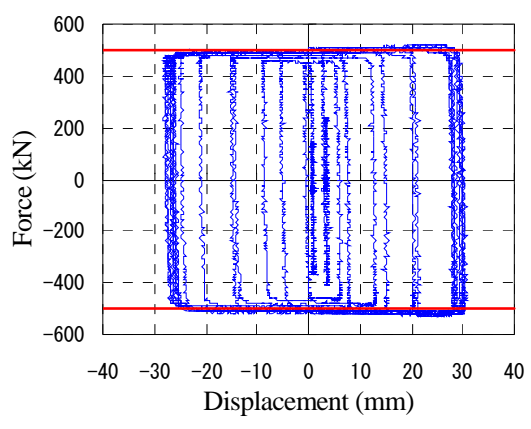

(a) Uni-axis test

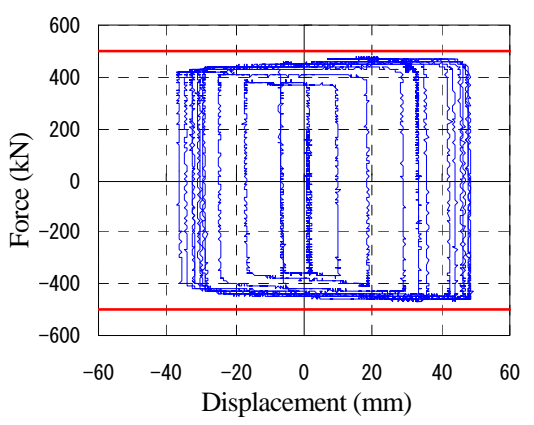

(b) Bi-axis test

Fig. 9 Hysteresis of trigger system

位も約 $20 \mathrm{~mm}$ 程度生じている. これと比較して，アクチュエータを試験体に接続しアクティブ制御を行なったア クティブ免震では，建物頂部の加速度がパッシブ免震の約 $1 / 10$ 程度まで低減されており，建物が絶対空間上にほ ぼ静止している状態が実現されている．免震層変位も地動変位の $10 \mathrm{~mm}$ 程度におさまっていることがわかる．ま た,ここではアクチュエータの変位指令值は図示していないが, アクチュエータ変位計測値とほぼ一致している.

\section{4. トリガー機構の開発}

アクティブ免震手法を実建物へ適用するのに際し，フェールセーフ機構としてのトリガー機構を開発した. ト リガー機構は，建物への過大入力を防ぐためアクチュエータと直列に設置し，摩擦機構によりすべり耐力以上の 荷重が加わるとすべり始める.この機構により，アクチュエータの制御可能な範囲を超えた地震動が作用した場 合や，万一アクチュエータの制御が不能になりアクチュエータが暴走した場合に，すべり而力以上の荷重が建物 に作用することはない，同時に，アクチュエータに過度の荷重が作用するのを防ぎ，アクチュエータを損傷から 保護する.

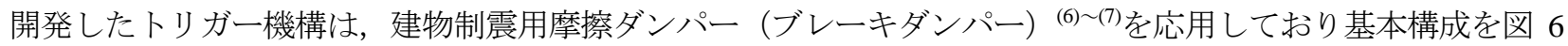
に示す．スプライスプレートとの間に一定の摩擦係数が得られるようステンレス板とブレーキ材で摩擦面を形成 し，摩擦面の圧力を一定に保つため適度にたわませた皿バネを介してボルトで締結することで，一定のすべり耐 力を確保する構造となっている.

ブレーキダンパーの復元力特性は，初期剛性が非常に大きく二次剛性が非常に小さい剛塑性型バイリニアモデ ルで表現できる．復元力特性を図 7 に示す. 


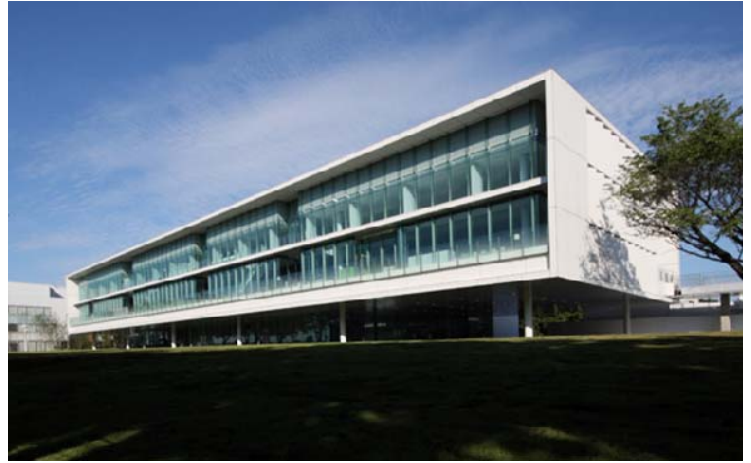

Fig. 10 Photo of active base isolated building

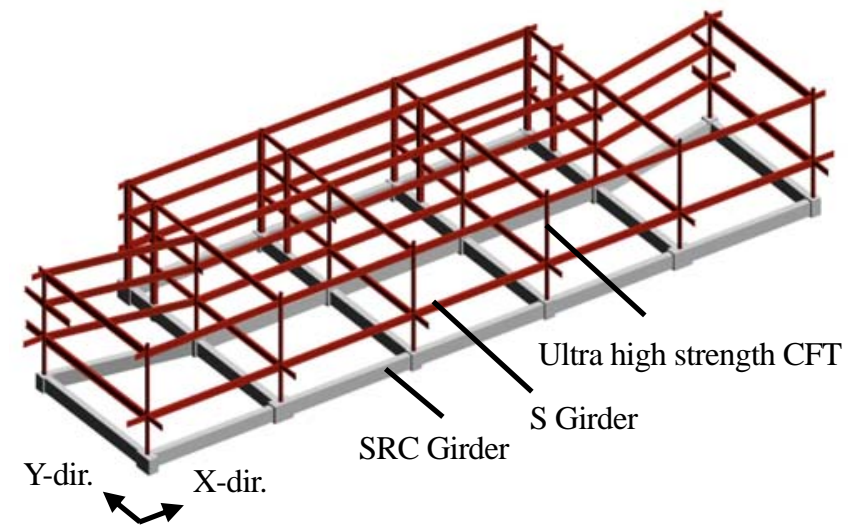

Fig. 11 Structural framing of upper structure

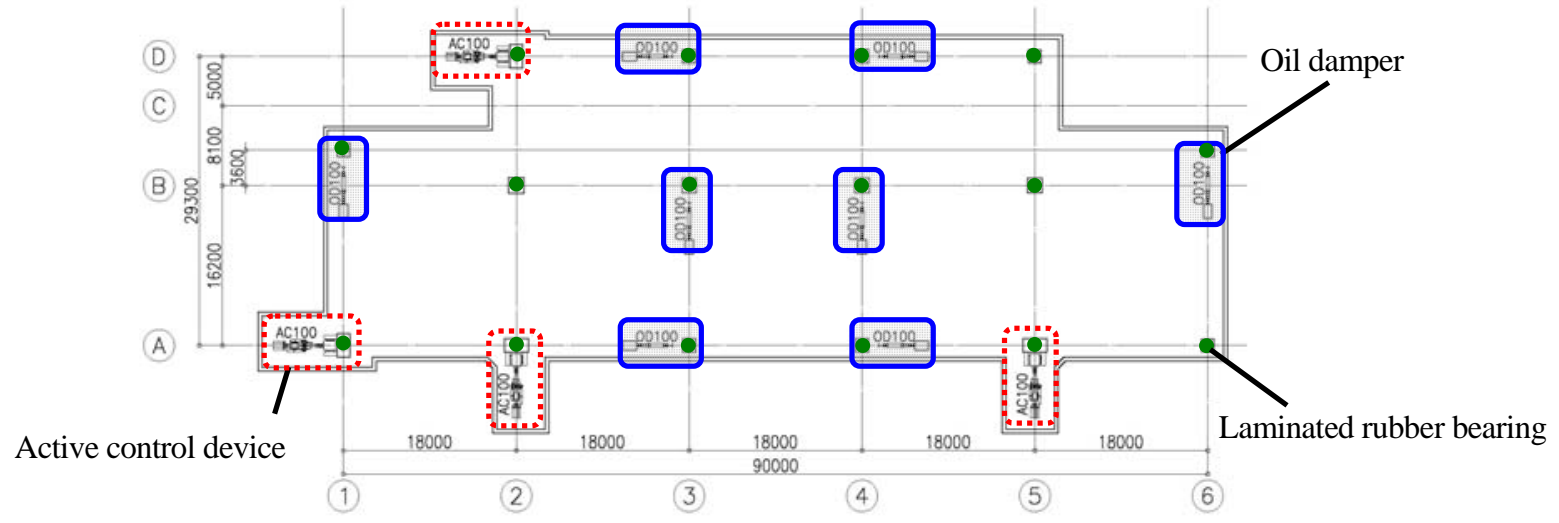

Fig. 12 Layout of devices on isolation floor

トリガー機構のすべり耐力および動作性を確認するために振動台を用いて動作確認実験を行った，実験は，振 動台を 1 軸方向（トリガー機構の動作方向）および 2 軸方向（トリガー機構の動作方向と直交方向）に正弦波お よび地震波で加振し, 式(7)に示した絶対制震理論によるフィードフォワード制御のうち地動変位に対するフィー ドフォワード指令值に追従するようにアクチュエータを制御した。これにより，アクチュエータの荷重がトリガ 一機構のすべり耐力以上となるとトリガー機構がすべりはじめることとなる. 実大規模卜リガー機構の検証試験 体とブレーキダンパー部分の拡大の写真を図 8 に示す。試験体は 6 つのブレーキダンパーユニットで構成し，す ベり耐力は $500 \mathrm{kN}$ に設定した.

振動台を 1 軸方向および 2 軸方向に周期 5 秒の正弦波, 振幅 $200 \mathrm{~mm}$ で加振した場合のトリガー機構の荷重-変 位関係を図 9 に示寸.ここで, 2 軸方向試験での荷重は, アクチュエータ長さ $3660 \mathrm{~mm}$ に対して直行方向振幅は最 大でも $200 \mathrm{~mm}$ と分小さいため, アクチュエータ稼働軸方向の荷重をトリガー機構の荷重とほぼ等しいとして用 いている．この結果より，トリガー機構の荷重は寸べり耐力 450～550kN で滑らかに作動し，アクティブ制御装 置に過大な荷重が作用しないことを確認できた．また，地震波加振の場合でも良好な履歴ループを確認した．

\section{5. 実建物への適用}

本アクティブ免震手法を適用した建物は，東京都清瀬市にある大林組技術研究所本館「テクノステーション」 で, 技術研究所の中心的建物である. 建築規模は地上 3 階, 高さ $16.1 \mathrm{~m}$ である. 1 階はエントランスホールや講 堂，2 階は 200 名程度を収容できるワークスペース（研究員の執務室）を配置し，3 階はワークスペース上部が吹 抜となっている. 東西方向（X方向） 96.85m，南北方向（Y 方向）33.5m の整形な平面形状である. 図 10 に外観 写真を示寸. 


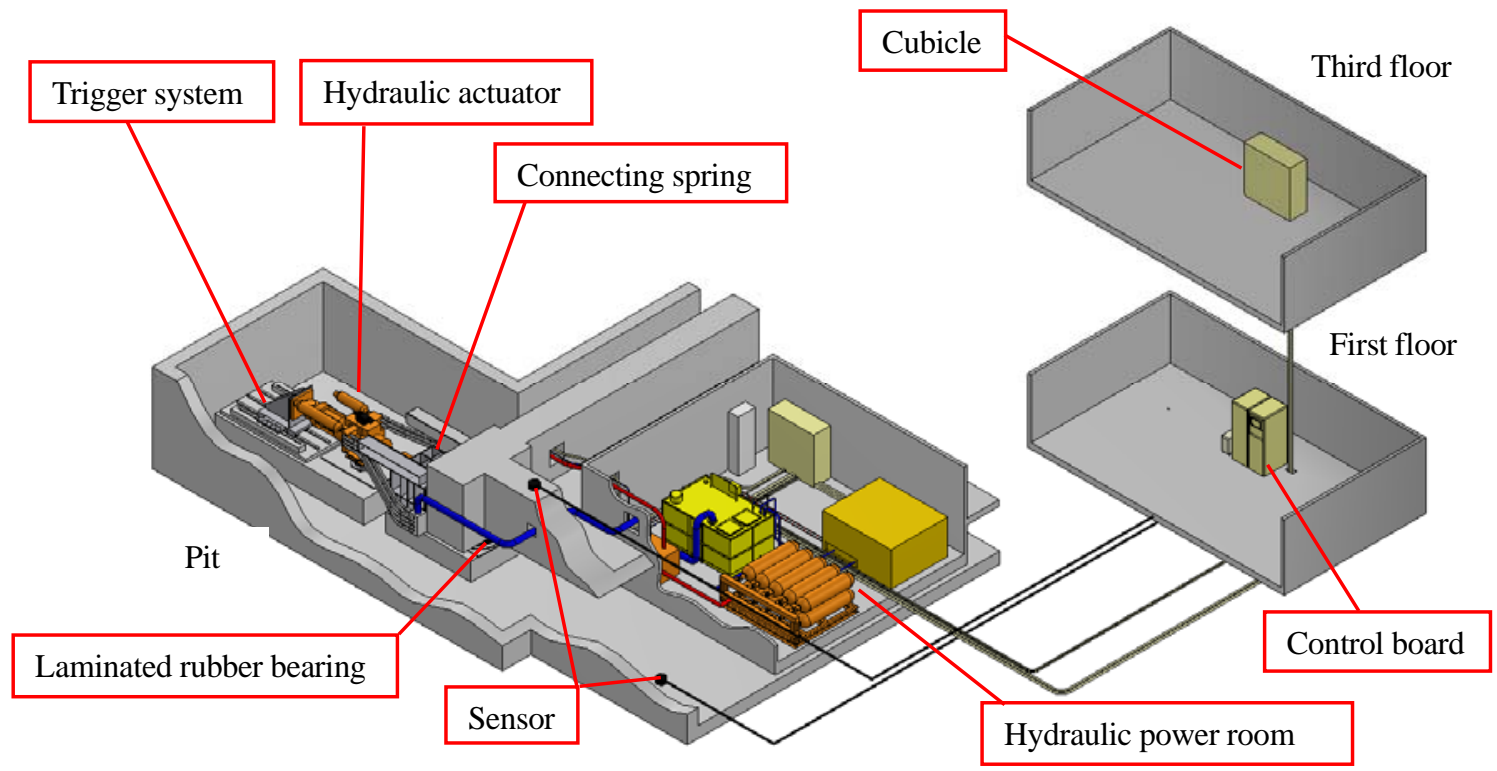

Fig. 13 Configuration of active control system

\section{$5 \cdot 1$ 構造計画概要}

上部構造は $\mathrm{S}$ 造ラーメン構造とし，東西 $(\mathrm{X})$ 方向 $18.0 \mathrm{~m} \times 5$ スパン，南北 $(\mathrm{Y})$ 方向 $19.8 \mathrm{~m} \sim 16.2 \mathrm{~m}+8.1 \mathrm{~m}+5.0 \mathrm{~m}$ の 3 スパン，階高は 1 階 5.5m，2〜3 階 4.0m である．ワークスペース部では $18.0 \mathrm{~m} \times 16.2 \mathrm{~m}$ のロングスパン架構を実 現するため, 梁は S 造, 柱は超高強度鋼材 $\left(\mathrm{Fu}=780 \mathrm{~N} / \mathrm{mm}^{2}\right)$ と超高強度コンクリート $\left(\mathrm{Fc}=160 \mathrm{~N} / \mathrm{mm}^{2}\right)$ による CFT

（鋼管コンクリート；Concrete Filled Steel Tube）造柱とした. 免震層直上の梁は，積層ゴムの反力を受けるため SRC 造とした. 図 11 に上部構造の構造フレームを示寸.

免震層は，天然ゴム系積層ゴム 16 台 $(\phi 800 \sim \phi 1100)$, オイルダンパー8 台 $(\mathrm{X}, \mathrm{Y}$ 方向各 4 台 $)$, アクティブ 制御装置 4 台（X，Y 方向各 2 台）をバランスよく配置した. 免震層の長周期化がアクティブ制御力の低減に有 効であるので, 免震層の一次固有周期を約 5.2 秒とした. 図 12 に免震装置のレイアウトを示す.

\section{$5 \cdot 2$ アクティブ制御装置の構成}

図 13 に示寸ように, アクティブ制御装置は, 装置バネをアクチュエータの建物側に, トリガー機構をアクチュ エータの地盤側に直列に配置する構成とした. アクティブ制御装置の各構成要素の機能を以下に示す.

\section{$5 \cdot 2 \cdot 1$ アクチュエータ}

ここで用いているアクチュエータは油圧アクチュエータである. 油圧アクチュエータはオイルタンク, 油圧ポ ンプなどの油圧源装置，油圧を蓄圧しておくアキュムレータと合わせて油圧回路を形成し，アクチュエータの駆 動にサーボバルブを組み込むことにより油圧サーボメカニズムとして機能する．加速度センサーからの入力信号 をもとに計算された変位指令值によって制御され，建物を絶対空間上に静止させるようにアクティブ制御力を建 物に作用させる. アクチュエータ 1 台あたりの最大発生力は $1100 \mathrm{kN}$, 最大制御変位は $200 \mathrm{~mm}$ である. アクチュ エータ実機の写真を図 14 に示し, 主な仕様を表 1 にまとめる. 本アクチュエータは, 加力方向と直行方向には抵 抗にならないように，ロッドの先端部と本体の後端部がクレビスによるピン接合となっており，アクチュエータ の自重は皿バネと転がり支承からなる自重支持装置で支持されている.

\section{$5 \cdot 2 \cdot 2$ トリガー機構}

トリガー機構は 1 基あたり 10 セットの皿バネボルトセットから構成され，トリガー機構の設計すべり而力は, アクチュエータの最大制御力 $1100 \mathrm{kN}$ を考慮して, $1000 \mathrm{kN}$ に設定した. 限界変形は, 免震装置の限界変形 $500 \mathrm{~mm}$ 


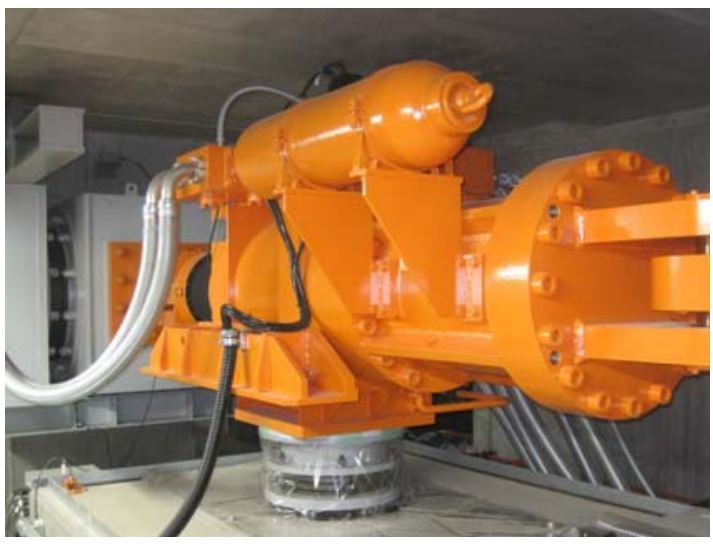

Fig. 14 Photo of hydraulic actuator

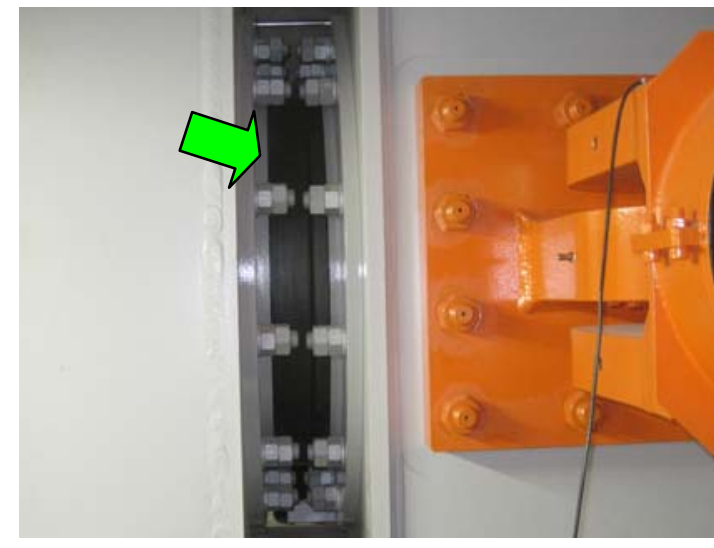

Fig. 16 Photo of Connecting Spring

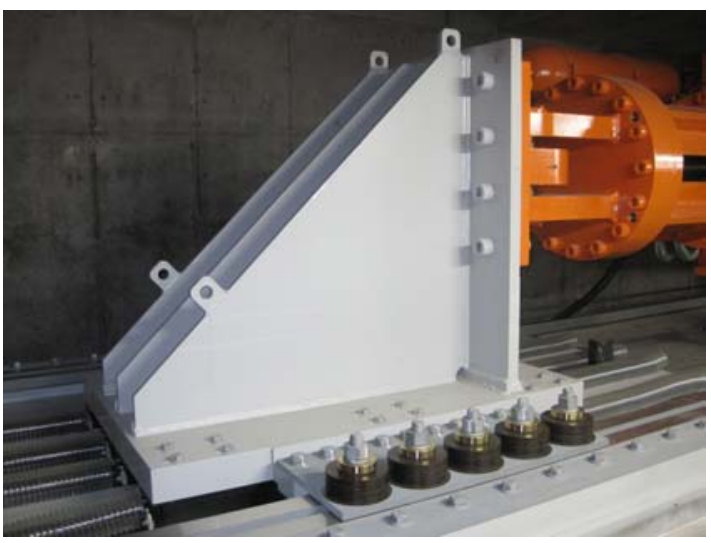

Fig. 15 Photo of trigger system

Table 1 Specification of hydraulic actuator

\begin{tabular}{l|l}
\hline No. & 4 \\
\hline Maximum force & $1100 \mathrm{kN}$ \\
\hline Maximum stroke & $200 \mathrm{~mm}$ \\
\hline
\end{tabular}

Table 2 Specification of trigger system

\begin{tabular}{l|l}
\hline No. & 4 \\
\hline Yield strength & $1000 \mathrm{kN}$ \\
\hline Maximum stroke & $750 \mathrm{~mm}$ \\
\hline
\end{tabular}

Table 3 Specification of connecting spring

\begin{tabular}{l|l}
\hline No. & 8 \\
\hline Stiffness & $16300 \mathrm{kN} / \mathrm{mm}$ \\
\hline Maximum stroke & $58.0 \mathrm{~mm}$ \\
\hline
\end{tabular}

とアクチュエータの最大制御変位 $200 \mathrm{~mm}$ を考慮して $750 \mathrm{~mm}$ とした. トリガー機構実機の写真を図 15 に示し, 主な仕様を表 2 にまとめる.

\section{$5 \cdot 2 \cdot 3$ 装置バネ}

装置バネとしては，弾性滑り支承用の積層ゴムを使用した。アクティブ制御装置 1 箇所あたり 2 基，合計 8 基 用いている。 その写真を図 16 に示し，主な仕様を表 3 にまとめる.

\section{$5 \cdot 2 \cdot 4$ 加速度センサー}

地動用の加速度センサーは建物基礎中央部に設置した. 建物用の加速度センサーは免震層直上の各アクチュエ 一タの先端付近に設置し，建物のねじれ応答に対しても制御できるようにした。

\section{$5 \cdot 2 \cdot 5$ コントローラー}

システムの制御を行なうコントローラは，建物 1 階の管理室に設置し，サンプリング周波数 $5 \mathrm{kHz} て ゙$ 制御を行 なう。

\section{$5 \cdot 3$ アクティブ制御装置の地震時の挙動}

アクティブ制御装置の地震時の挙動は以下の 4 ケースを想定し構造設計を行い，全てのケースについて免震装 置及び上部構造物を健全に保つことができることを確認している. 
Table 4 Parameters for base isolated building

\begin{tabular}{|c|c|c|c|c|c|c|c|}
\hline \multirow{2}{*}{\multicolumn{2}{|c|}{ Floor }} & \multirow{2}{*}{\multicolumn{2}{|c|}{ Mass(ton) }} & \multicolumn{4}{|c|}{ Initial Stiffness (kN/mm) } \\
\hline & & & & \multicolumn{2}{|c|}{ X-dir. } & \multicolumn{2}{|c|}{ Y-dir. } \\
\hline $\mathrm{RF}$ & & 2237 & - & 317.3 & 55.9 & 407.6 & 47.0 \\
\hline $3 F$ & $3 \mathrm{~F}-\mathrm{a}$ & 771 & 170 & 316.1 & 63.0 & 371.4 & 51.9 \\
\hline $2 \mathrm{~F}$ & & 2101 & - & 425.7 & - & 513.9 & - \\
\hline $1 \mathrm{~F}$ & & 4466 & - & 14.2 & - & 14.2 & - \\
\hline
\end{tabular}

Table 5 Parameters for oil dampers

\begin{tabular}{c|c|c|c|c}
\hline & $\mathrm{C}_{1}(\mathrm{MN} \cdot \mathrm{s} / \mathrm{m})$ & $\mathrm{C}_{2}(\mathrm{MN} \cdot \mathrm{s} / \mathrm{m})$ & $\mathrm{F}_{\mathrm{r}}(\mathrm{kN})$ & $\mathrm{F}_{\max }(\mathrm{kN})$ \\
\hline X,Y-dir. & 5.08 & 0.772 & 3532 & 3920 \\
\hline
\end{tabular}

Table 6 Parameters for active devices

\begin{tabular}{c|c|c}
\hline & $\begin{array}{c}\text { Connecting spring } \\
\text { Stiffness }(\mathrm{kN} / \mathrm{mm})\end{array}$ & $\begin{array}{c}\text { Trigger system } \\
\text { Yield strength }(\mathrm{kN})\end{array}$ \\
\hline X,Y-dir. & 68.6 & 2000 \\
\hline
\end{tabular}

Case 1

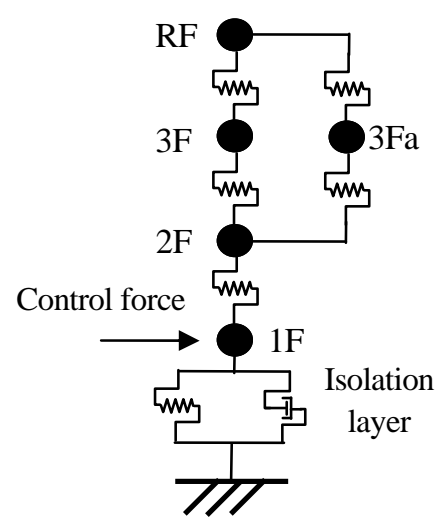

Case 4

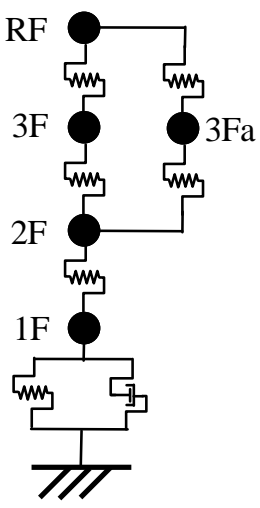

Fig. 17 Analysis models

\section{$5 \cdot 3 \cdot 1$ Case1 アクティブ制御装置が正常に作用する場合}

アクチュエータは正常に制御できるが，トリガー機構にすべり耐力以上の荷重が作用した場合にはトリガー機 構がすべり，建物に過大な入力は生じない．

\section{$5 \cdot 3 \cdot 2$ Case2 アクティブ制御装置に異常があるが制御可能な場合}

アクチュエータは位置を保持する制御もしくは強制的に可動しない制御とする. アクティブ制御装置は, 装置 バネの剛性を初期岡性，トリガー機構のすべり耐力を降伏荷重とする履歴ダンパーとして作用する.

\section{$5 \cdot 3 \cdot 3$ Case3 アクティブ制御装置に異常があり制御不可能な場合}

アクチュエータは暴走するが，トリガー機構にすべり而力以上の荷重が作用した場合にはトリガー機構がす心゙ り，建物に過大な入力は生じない.

\section{$5 \cdot 3 \cdot 4$ Case4 アクティブ制御装置をはずしている場合（パッシブ免震となる場合）}

アクチュエータをメンテナンス等で取り外している場合などのように，アクティブ制御装置がない場合は，天 然ゴム系積層ゴムとオイルダンパーによるパッシブ免震システムとなる.

\section{$5 \cdot 4$ 地震応答解析結果}

本アクティブ免震手法が適用される実建物を対象として時刻歴応答解析を行い，その効果を検証する．アクテ イブ免震を適用した場合と通常のパッシブ免震の場合の比較を行なうために, ここで紹介する解析ケースは以下 の 2 ケースとした.

Case1 アクティブ制御装置が正常に作用寸る場合

Case4 アクティブ制御装置をはずしている場合（パッシブ免震となる場合）

解析モデルは 5 質点の等価せん断型モデルとした。 ここで, 本建物は 3 階の中央部が吹抜の大空間となってい るため, 3 階は吹抜両側で分割した 2 質点でモデル化している．復元力特性は，上部構造は線形弾性，免震層は 天然ゴム系積層ゴムを線形弾性, オイルダンパーの減衰係数を速度比例のバイリニア型（初期減衰係数 $C_{1}$, リリ 一フ後減衰係数 $C_{2}$, リリーフ減衰力 $F_{r}$, 許容最大減衰力 $F_{\max }$ ) とした. アクティブ制御装置は, Case 1 では正 常作動とし，Case4では除外した。解析モデルを図 17 に，解析諸元を表 4〜表 6 に示す. 


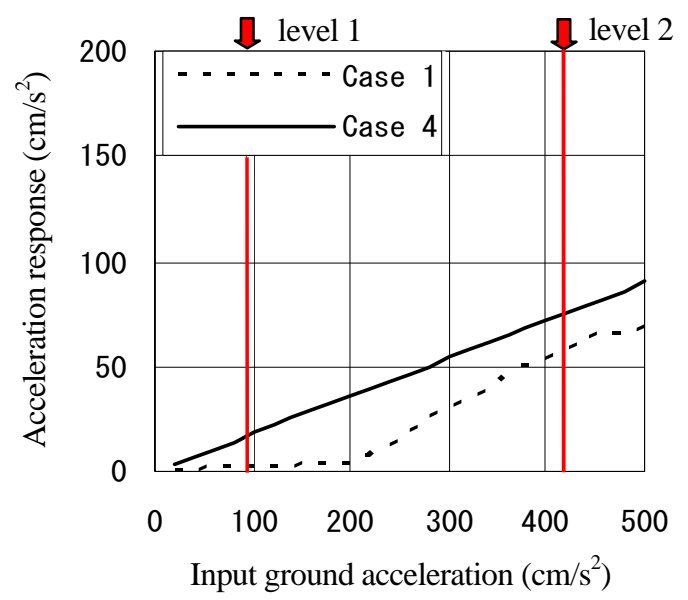

Fig. 18 Acceleration responses due to input level (RN1H, X-dir.)
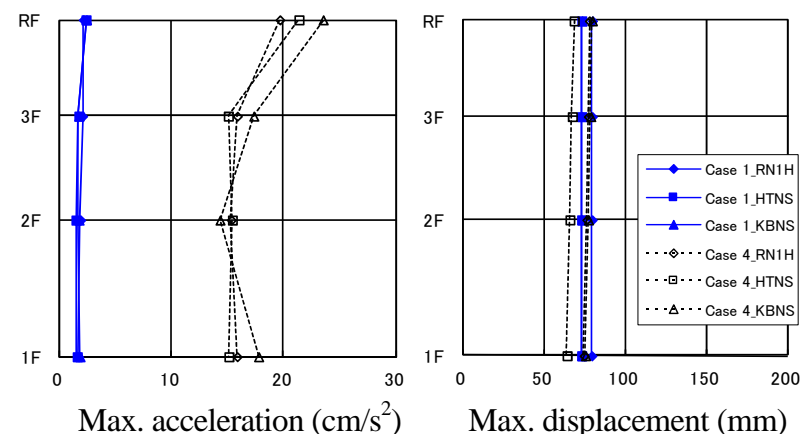

Max. displacement (mm)

Fig. 19 Maximum responses for level 1 input ground motion (X-dir.)

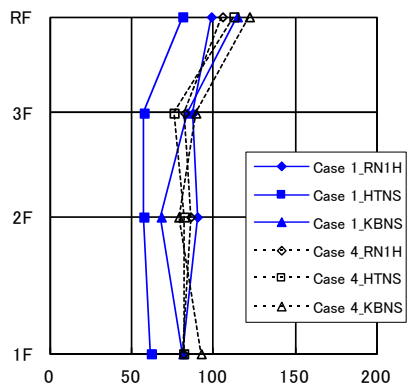

Max. acceleration $\left(\mathrm{cm} / \mathrm{s}^{2}\right)$

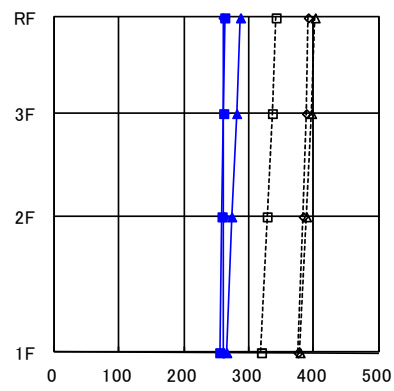

Max. displacement (mm)

Fig. 20 Maximum responses for level 2 input ground motion (X-dir.)

入力地震動は, 告示波として稀に発生する地震動（level 1）および極めて稀に発生する地震動（level 2）の $2 つ$ のレベルを設定し，それぞれ 3 波（乱数位相[RN1H], 八戸NS 位相[HTNS], 神戸 NS 位相[KBNS]）とした. ここ で，告示波とは，建設省告示第 1461 号（平成 12 年 5 月 31 日）にて規定された解放工学的基盤における加速度応 答スペクトルをもとに作成した告示スペクトル適合波に，建物建設地（本建物の場合は東京都清瀬市）の表層地 盤の増幅と考慮して作成した模擬地震波のことであり，耐震性能の評価を受ける際には，告示波 3 波以上で時刻 歴応答解析を行い，建物性能を検証することが求められている．また，稀に発生する地震動（level 1）は再現期 間 50 年程度の中地震, 極めて稀に発生する地震動（level 2）は再現期間 500 年程度の大地震とされている.

以下，本論文では X 方向の応答解析結果について述べる.

\section{$5 \cdot 4 \cdot 1$ 稀に発生する地震動に対する応答}

告示波（乱数位相）入力地震動最大加速度と最大応答加速度の関係を図 18 に示寸. また, 稀に発生する地震 動に対する時刻歴応答解析による最大応答加速度および最大応答変位を図 19 に示す.

免震層の最大応答变位は Case1, Case4 ともに $80 \mathrm{~mm}$ 程度と大きな差はなく, 免震層上部 $(1 \mathrm{~F})$ の最大応答加 速度は Case1 で $1.9 \mathrm{~cm} / \mathrm{s}^{2}$, Case4 で $17.8 \mathrm{~cm} / \mathrm{s}^{2}$ であり, アクティブ免震の応答はパッシブ免震と比較し $1 / 10$ 程度と なった。これは，アクチュエータの制御力（最大 $1219 \mathrm{kN} / 2$ 基）がトリガー機構の寸べり耐力（2000kN/2 基）以 内におさまったため, アクティブ制御が高い効果を発揮したことによる.

\section{$5 \cdot 4 \cdot 2$ 極めて稀に発生する地震動に対する応答}

極めて稀に発生する地震動に対する時刻歴応答解析による最大応答加速度および最大応答変位を図 20 に示す.

図 20 から, 免震層の最大応答変位は Case1 で 265.4mm, Case4 で 378.4mm, 免震層上部（1F）の最大応答加速 度は Case1 で $81.1 \mathrm{~cm} / \mathrm{s}^{2}$, Case4 で $92.3 \mathrm{~cm} / \mathrm{s}^{2}$ であり, アクティブ免震の応答はパッシブ免震と比較し小さくなった. 
これは, アクチュエータの制御力がトリガー機構のすべり耐力に達しても, アクティブ制御の効果があることを 示している.

また, 図 18 から, 入力地震動最大加速度が $200 \mathrm{~cm} / \mathrm{s}^{2}$ 程度までは, アクティブ制御の効果が大きいことがわか る.

\section{6. 結 語}

地震時にも摇れない建物の実現を目指した絶対制震理論によるアクティブ免震手法を開発し，世界で初めて実 建物に適用した.

本システムでは, 絶対制震理論に基づいて計算された最適な制御力をアクチュエータによって建物に作用させ, パッシブ免震建物と比較して加速度応答を $1 / 10$ 程度まで低減することができる. その制御効果を縮小模型による 振動台実験で検証した．また，実建物適用に際して，想定した地震を超える大地震時や万が一アクティブ制御装 置に不具合が生じた場合のフェールセーフ機構として, 摩擦によるトリガー機構を開発した.

本システムが適用された大林組技術研究所本館「テクノステーション」では, 水平 2 方向に $1100 \mathrm{kN}$ の油圧アク チュエータを 2 台ずつ配置し, $200 \mathrm{~cm} / \mathrm{s}^{2}$ 程度の入力地震動までは, アクティブ制御により建物がほとんど摇れず, それより大きくトリガー機構の寸べり耐力に達する入力地震動に対してもパッシブ免震と比較して加速度低減効 果があることを解析により確認した。

本アクティブ免震手法は, 地震時に事業継続が必要な半導体工場などの精密生産施設, 地震時に機能維持が求 められる病院や災害の復旧拠点, 貴重品が保管される美術館や博物館, 絶対的な安全が求められる原子力関連施 設へ適用するのに適していると考えられる.

\section{文献}

（1）武田寿一編，構造物の免震・防振・制振（1988）， p. 121，技報堂出版.

（2）野畑有秀，蔭山満，鈴木哲夫，関松太郎，岡田宏，武田寿一，“構造物の制振に関する研究（その 3 . 絶対応答量 に基づく制振の基本概念)”, 日本建築学会大会学術講演梗概集, Vol.B-2（1988），pp.507-508.

（3）䔖山満, 野畑有秀, 寺村彰, 関松太郎, 鈴木哲夫, 武田寿一, “構造物の制振に関寸る研究（その 4 . 絶対制振の 基礎的実験)”, 日本建築学会大会学術講演梗概集, Vol.B-2 (1988), pp.509-510.

（4）蔭山満，野畑有秀，寺村彰，鈴木哲夫，岡田宏，安井譲，“構造物の制振に関する研究（その 5 . 多層構造物の絶 対制振に関する理論的検討)”, 日本建築学会大会学術講演梗概集, Vol.B-2 (1989), pp.563-564.

(5) 野畑有秀, 蔭山満, 寺村彰, 関松太郎, 岡田宏, 安井譲, “構造物の制振に関寸る研究（その6. 多層構造物の 絶対制振に関する実験)”, 日本建築学会大会学術講演梗概集，Vol.B-2 (1989), pp.565-566.

(6) 高橋泰彦, 鈴井康正, “高力ボルト摩擦接合滑りダンパーの開発（その 1 . ダンパー概要と要素単体の基礎動的実 験)”, 日本建築学会大会学術講演梗概集, Vol.B-2 (2000), pp.979-980.

(7) 鈴井康正, 高橋泰彦, “高力ボルト摩擦接合滑りダンパーの開発（その 2 . 実大ダンパー付きブレースの大型振動 台実験)”, 日本建築学会大会学術講演梗概集, Vol.B-2 (2000), pp.981-982. 